\title{
Cell events in cambium, connected with the formation and existence of a whirled cell arrangement*
}

\author{
WIESH AW WŁOCH \\ Department of Biophysics and Cell Biology, Silesian \\ University, Katowice \\ (Received: April 13, 1976)
}

\begin{abstract}
The history of cambium development was reconstructed on the basis of serial tangential sections of a woody tumour of Picea excelsa (Lam.) Lk. On the area with whirled arragement of the tracheids intrusive growth was found to occur at the lateral radial and longitudinal edges apart from its normal occurrence at the radial apical edges. Intrusive growth at the radial lateral edge leads to forking of the fusiform initial in the cambium plane. The growth which appears on longitudinal lateral edges occurs between the tangential walls of cells in neighbouring storeys. In such places a drastic reconstruction of the cell arrangement in meighbouring annual rings was observed. Intrusive growih between the tangential walls leads to a whirled arrangement of tracheids.
\end{abstract}

\section{INTRODUCTION}

Intrusive growth of initial cells occurs in the cambium and its consequences are: anticlinal divisions, overlapping of cell ends oriented in opposite directions, elimination of cells, separation and joining of rays (Hejnowicz, 1967). This growth occurs in two alternative configurations: either "to the right" or "to the left". Within the cambium areas called domains can be distinguished according to the configuration of events.

Cambium of coniferous trees produces straight-grain wood, but locally in tumour state and on stumps ( $\mathrm{Ne}$ ef, 1922) it may form wavy-grain wood. Tumour cambium differs from that forming normal wood by a higher intensity of oriented events in the domains (Hejnowicz, 1971).

* This work was supported in part by a grant from the U.S. Department of Agriculture (under Public Law 480). 
The wavy arrangement of wood elements is the consequence of domain structure in the cambium and of the higher intensity of the oriented events. The amplitude of the wavy grain depends on the frequency of cellular events in the cambium and it is zero in straght-grain wood.

Within the woody tumour in spruce and also in living stumps there occur, beside areas with regular waviness, regions with a more complicated tracheid arrangement. Regular waviness is characterized by: a smooth phase fronts running more or less transversally to the stem axis, $\mathrm{b}$ - continuity of the change in the deflection of the tracheids observed as we advance along the stem. Complications in tracheid arrangement are manifested in the occurrence of phase shifts and amplitude leaps in neighbouring longitudinal sectors and in wide local bends of the tracheids. Some of the latter are bent so that their basal and apical ends are oriented in the same direction in the tangential plane (Fig. 1). The area where

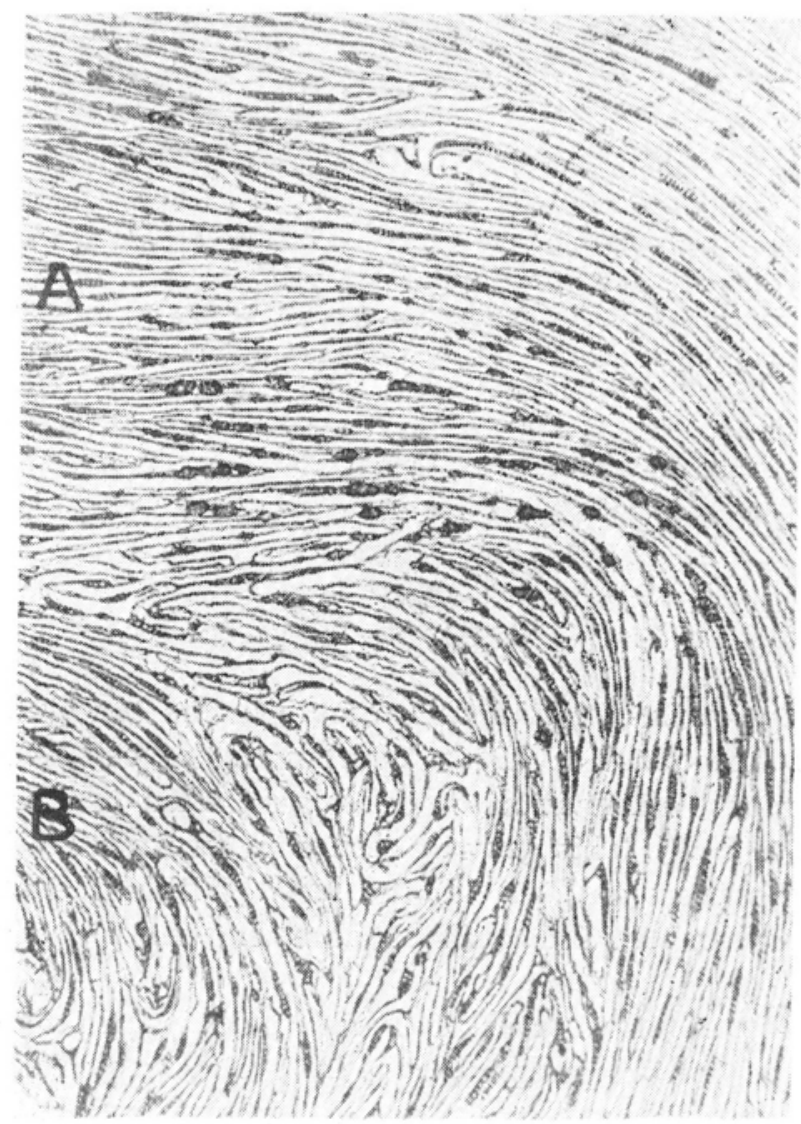

Fig. 1. Selected wavy area within tumour wood in Picea excelsa (tangential section). A - area with regular transversal wavy fronts (at the given level the waviness of the tracheids shows similar phases and amplitudes); B - area with disturbed front pattern, (inconformity on wavy course of tracheids as regards amplitude. phase and direction of wave course). Sites with whirled cell arrangement are visible 
strong bending to the cells occurs will be referred to as whirling. It may comprise one to more than a dozen cells. As a rule continuous changes of tracheid arrangement in the successive wood layers occur in whirling, this indicating that analogous changes occurred in the cambium cell arrangement.

The history of cambium development is inscribed in the wood and may be read from a series of tangential sections. The purpose of the present study was the reconstruction of the development of whirlings and follow-up of the events occurring in tumour cambium producing wood with whirled arrangement of tracheids in Picea excelsa (Lam.) Lk.

\section{MATERIAL'AND METHODS}

The material consisted of woody tumours occurring in Picea excelsa (Lam.) Lk. stems from the Tatra mountains. It was the same material as was used in the work of $\mathrm{He} \mathrm{j} \mathrm{n} \mathrm{ow} \mathrm{i} \mathrm{c} \mathrm{z} \mathrm{(1971)} \mathrm{"old} \mathrm{trees} \mathrm{with} \mathrm{scattered}$ lenticular-circular patches of wavy-grained xylem in their trunks". From tumour wood blocks $1 \times 1.5 \times 3 \mathrm{~cm}$ were cut and from these series of tangential sections were prepared $0.25 \mu \mathrm{m}$ and transversal ones $40 \mu \mathrm{m}$ thick with a sliding microtome. The sections were stuck with Haupt's adhesive to coverslips. After drying the latter were immersed alternately in boiling and cold ethyl alcohol in order to expel air. Then the sections were washed in xylene (changed 2-3 times and embedded in Canada balsam). The chosen fragments were photographed on successive sections. If necessary the photographs were supplemented by microscopic examination and drawings made with a drawing device. Part of the material was macerated in order to reveal the shape of the particular tracheids.

\section{RESULTS}

The examined woody tumour had the shape of a lens with dimensions on the stem surface (ca 90th annual ring): length $6 \mathrm{~cm}$, breadth $1 \mathrm{~cm}$. The lens began in the 10th annual ring at the time of formation of which there occurred an unknown injury which gave rise to the tumour state of the cambium. A small group of cambium cells of tumour character appeared. During formation of the subsequent 80 rings or so the lens of tumour cambium gradually increased in size up to the above given dimensions. In general the wood produced by this cambium was wavy and locally whiried arrangement (whirls) appeared in it.

In examination of the successive tangential sections the rays served as reference points. The distribution of the centres of the rays in the material changes according to the increase of the cambium surface. Only the distances in tangential transversal direction increased. 
In order to make the description of the events in cambium cells in whirled arrangement easier, the terminology introduced in Fig. 2 will be used.

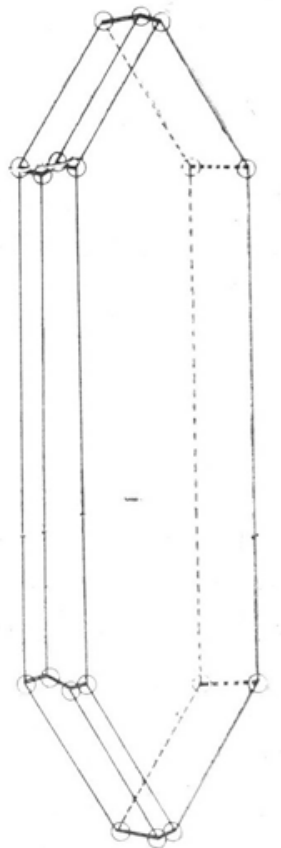

Fig. 2. Diagram of cambium cell illustrating various kinds of edges

Radial edges are marked with bold line, longitudinal ones with thin line. Among the radial edges some are apical and some lateral. The cornes are denoted by circles

Intrusive growth may occur at any edge of the cell, particularly close to the corners (Fig. 3). If it occurs at the radial edges the growing end intrudes between the radial walls of neighbouring cells belonging to two

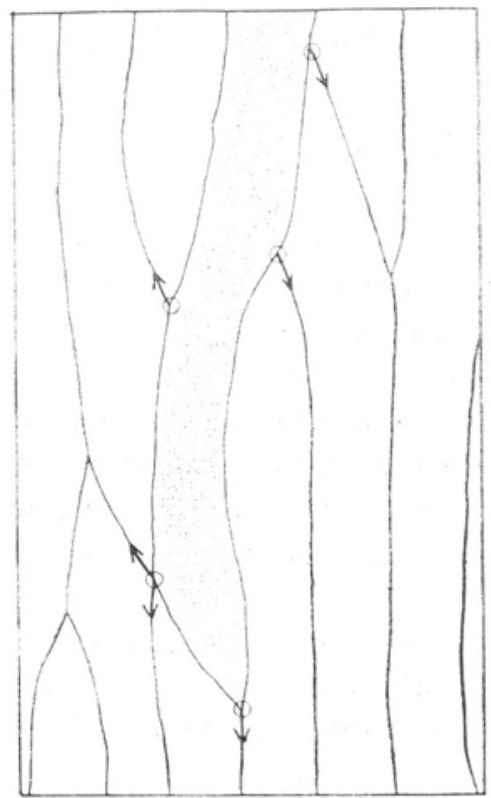

Fig. 3. Cambium cell in tangential cross section (doted area)

Sites of eventual intrusive growth close to the corners marked by circles. Arrow shows direction of eventual growth at radial edges 
different neighbouring storeys. Intrusive growth at the longitudinal edges means cell intrusion between the tangential walls of cells of one neighbouring storey (Fig. 4D). The growth of the longitudinal edge is mostly localized close to the corner. If the edge growing in this way belongs to an initial cell, then in the neighbouring storey into which this edge grows the fragment of the initial is eliminated. In the given storey, namely only one initial is active. Intrusive growth at the longitudinal edges is a frequent phenomenon in whirled cambium and is the cause of drastic reconstruction of the cells in the successive section (fig. $4 \mathrm{D}, \mathrm{H}, \mathrm{O}, \mathrm{B}^{\prime}, \mathrm{E}^{\prime}$ ). Between the tangential walls intrusive growth appears rather accidentlly and may be found usually at sites with serious disturbances in the tracheid arrangement.

A typical series of successive development stages of the whirled arrangement is shown in Fig. 4A-O, $\mathrm{A}^{\prime}-\mathrm{O}^{\prime}$. This series starts from the site where the tracheids do not yet exhibit bending. At first the cells run together under an angle and their ends accumulate on a small area (Fig. 4A-C). At a certain moment (Fig. 4C, D) the vertically hatched cell formed a forking because of intrusive growth at the long lateral edge in the region of the apical corner. This forking grows between the tangential walls of other cells transversally to their long axis (Fig. 4D). At a certain moment the forking of the cell changed its growth direction and continued to grow between the radial walls of neighbouring cells along their long axis in two directions - apical and basal. Thus, a forked cell arose (Fig. 4D, E). One may conclude that the forking occurred in the initial cells since there is a continuity of the change in shape in the successive tracheids of the given radial row. The branched initial is an obstacle to normal growth of other cells which cannot grow through it for a certain period, although they grow intrusively between the radial walls and become bent. The cells can grow through the obstacle only by way of growth between the tangential walls (Fig. 4E-O).

The whirled arrangement is not stable. The bending of the cells disappears either owing to intrusive growth of the initials along the tangential walls above or below the bend, or by way of anticlinal division of the cells forming the bend exactly at the site of the bend. In the latter case a double radial wall is formed along which the remaining cells grow normally.

The most pronounced reconstruction of the cell arrangement and numerous cell divisions are noticeable at the border of the annual ring. This is connected with the fact that at the border of the annual ring the wood layer comprises the history of a longer period than does the inner layer of the annual tring of the same thickness, and particularly its spring

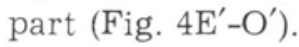

Simultaneous or nonsimultaneous intrusive growth on more than two radial edges leads to forking of cells. The additional edge is a lateral one. 

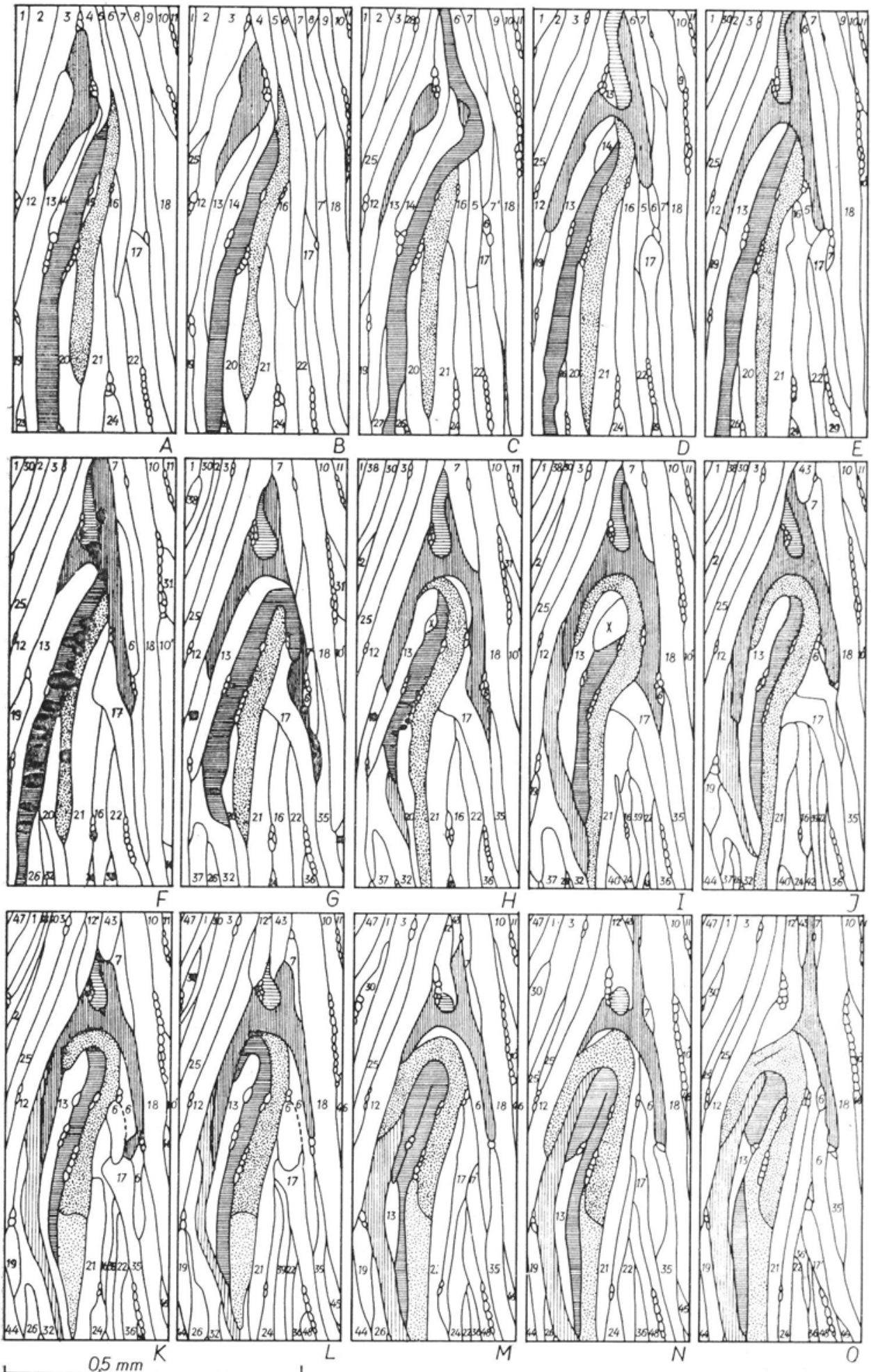

F:g. 4. Series of drawings made from 30 successive tangential sections of wood $25 \mu \mathrm{m}$ thick

The saries shows the successive stages of formation and disappearance of whirling. Most cells are denoted by figures. Cells of the same radial row bear the same figure. Cells having 


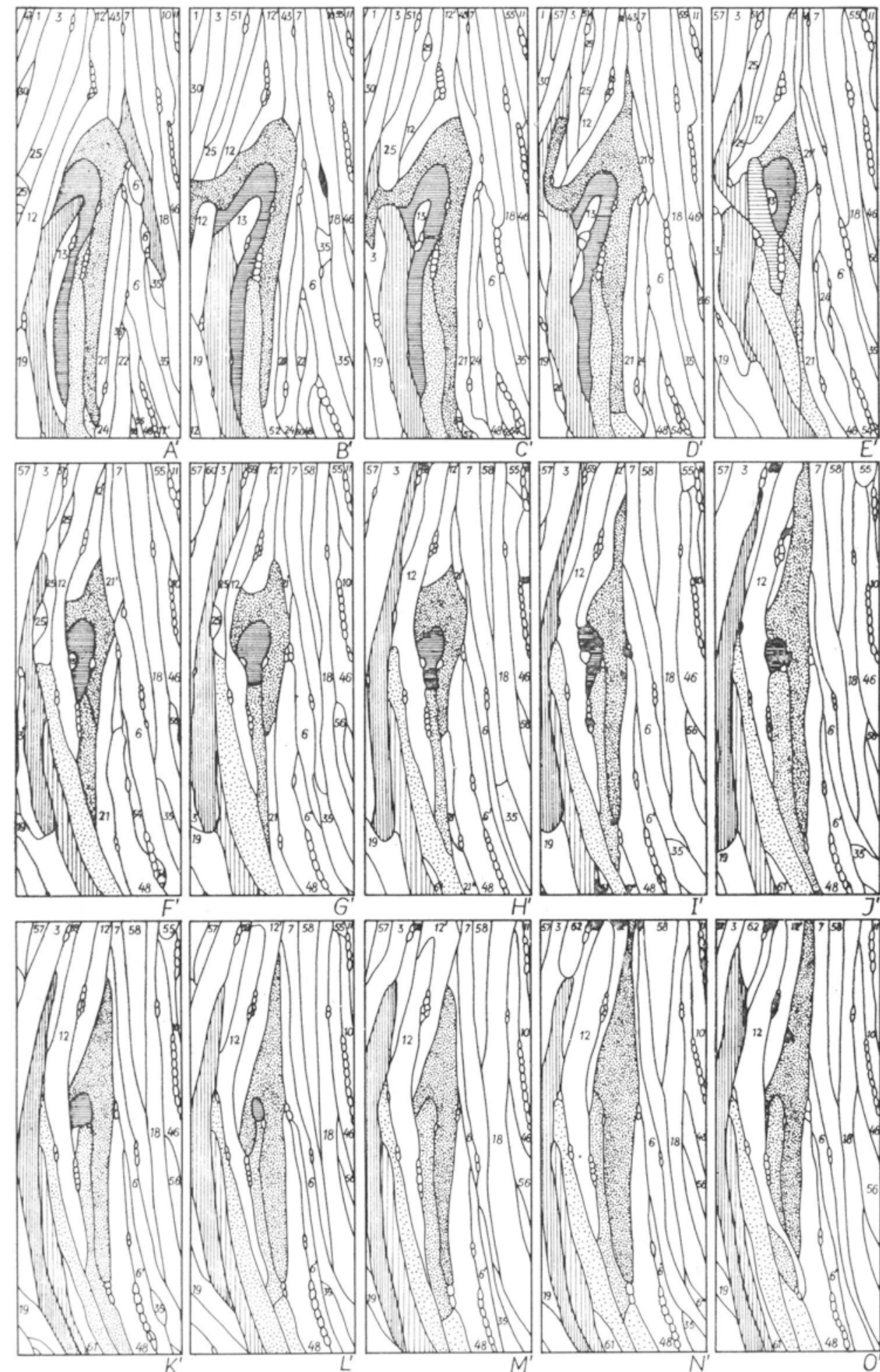

passed anticlinal division are also denoted by the same figure, one of them has an apostrophe next to it. Several cells, because of their different behaviour (description in text), are marked by hatched and dotted areas. The cells derived from them after anticlinal division are donoted by less and less dense hatching and dotting. The radial inrusion of cell no. 6 in figs $\mathrm{K}$ and $\mathrm{L}$ is denoted by an interrupted line. The cell denoted $\mathrm{X}$ is probably an intrusion 
Branching of the cell may occur at various distances from its end, and this in turn depends on the distribution of the ends of neighbouring cells (Fig. 5).
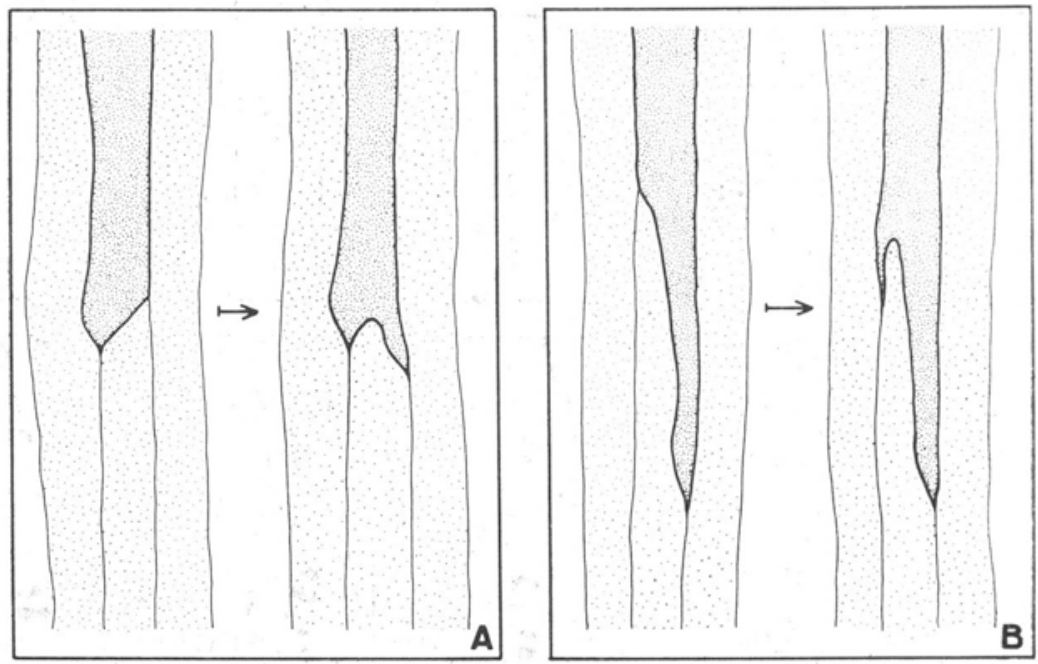

Fig. 5. Cambium cells in tangential cross section. Diagram of cell forking due to intrusive growth at lateral edge

A - Lateral edge close to apical edge; B - Lateral edge at a greater distance from apical one

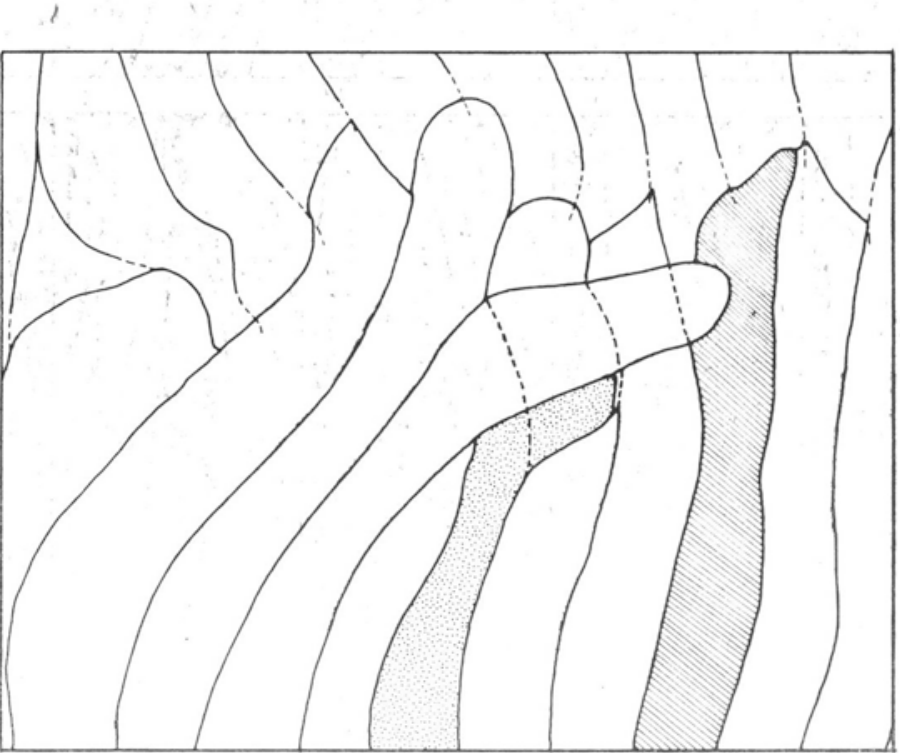

Fig. 6. Radial cross section through tumour wood, cambium on right

Local radial growth of cell over several layers visible. This growth blocked intrusion growth of somewhat younger sister cells to which belongs dotted cell. Hached cell caved in under the pressure of radially intruding cell. 
On radial and transversal cross sections and on serial tangential sections at the sites of whirled tracheid arrangement, cell intrusion in radial direction may be observed both centripetally and centrifugally, frequently over several cell layers. These intrusions occur locally in the given radial row, this indicating that either intrusive growth leading to this growth occurred in xylem mother cells or, in the case of initials, the plane of periclinal division did not comprise the radially directed part of the cell (Figs 6, 7).

It may happen that in a whirled arangement two ends of a bent ceil may grow in the tangential plane in the same direction. In some cases the bent end grows along the surface of the wall of its own cells. Then a double wall forms in this cell (Fig. 8A). Such a situation mostly occurs as follows: the bent cell growing between the tangential walls surrounds the neighbouring cell and then eliminates it.

Some cells exhibit local distensions with a lumen within the wall
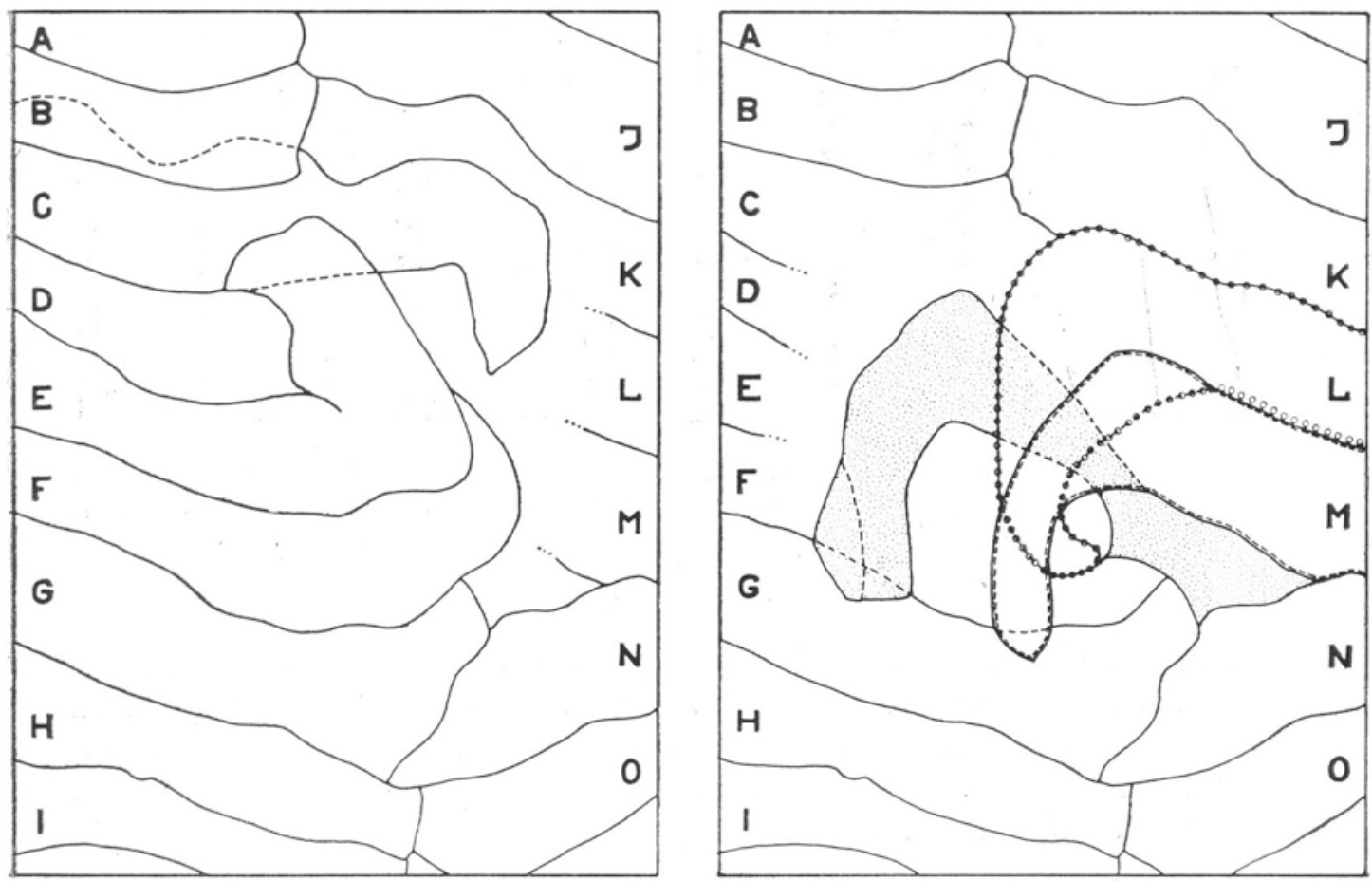

Fig. 7. Radial cross section through tumour wood showing bending of cell ends in radial plane

The ends of cambium cells grew intrusively between the radial walls deflected from the tangential plane. Since the bent ends are superposed the picture is divided into two parts. In the first only the upper ends of the first cell row are shown. Radial growth of a cell of the neighbouring layer is visible (dotted). To the vertical orientation in the stem (upwards) corresponds on the drawing the vertical direction to the right. Cambium on upper side of 

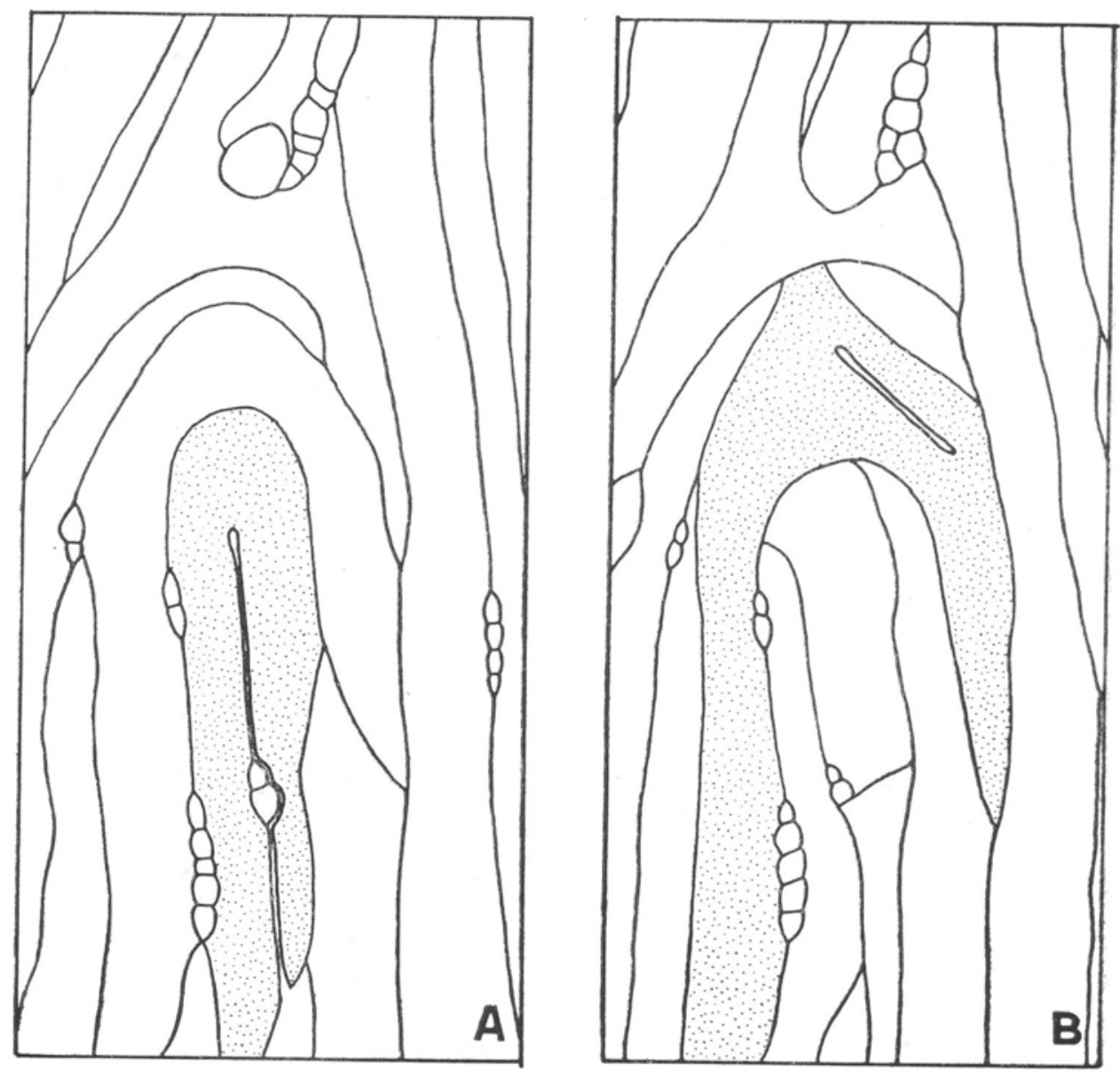

Fig. 8. Tracheids of whirled area - tangential cross section A - two ends of cell grow in the same direction. The bent end grows along the wall of its own cell. A double cell wall is formed; B - closed cavity in dotted cell

(Figs 8B, 10, 12, 13). Such a hole arises probably owing to caving in of the periclinal wall into the distended initial so that the newly formed periclinal walls contact the sides of this cave-in (Fig. 9). This cave-in which is the cause of formation of a cavity occurs under the pressure of a cell growing into the distended initial.

In areas with a seriously disturbed tracheid arrangement, at the sites of strong bending of fusiform cells the slope of the rays hardly changes it does not follow the course of the neighbouring whirled tracheids as is the case in wavy wood. This is so because the rays resist to the fusiform cells which drastically change their inclination. In the case of wavy wood the change in tracheid arrangement is not more rapid than the change of the radial slope. 


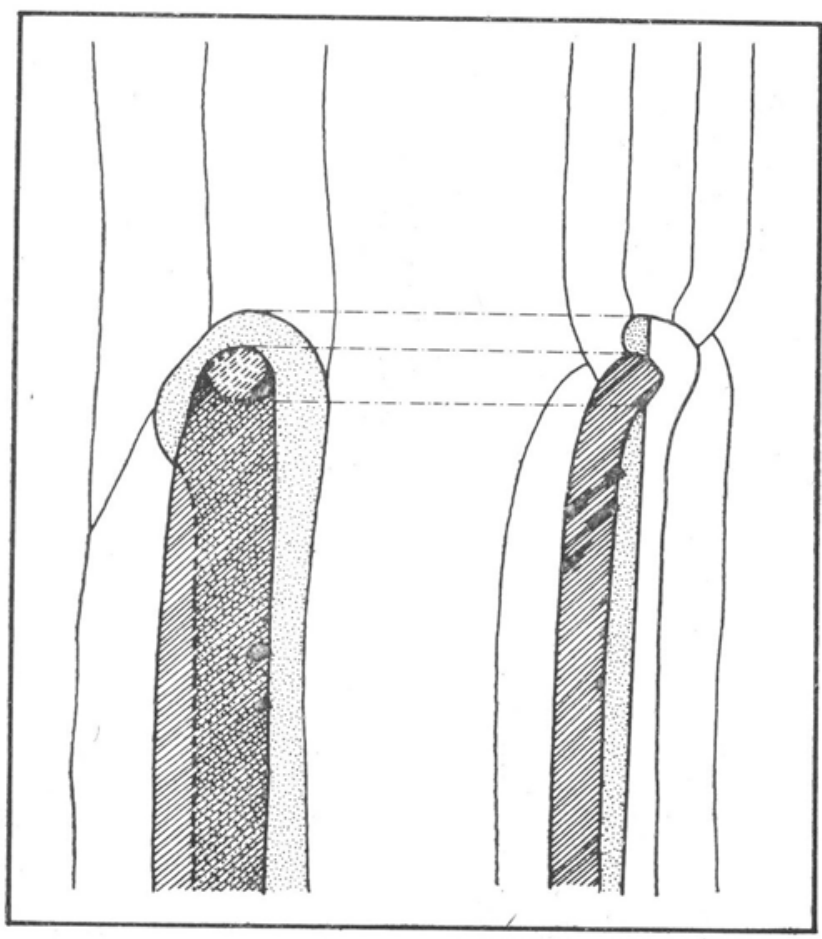

Fig. 9. Diagram illustrating formation of cavity in cell. Radial cross section on right side, tangential cross section on left

In tumour wood the height of the rays usually does not exceed several cells, whereas in normal wood it is several times higher. Splitting of the rays occurs by way of intrusion of fusiform cells between the radial walls.

\section{DISCUSSION}

Intrusive growth is a very important factor in the development of nonstoreyed cambium. It is the basic mechanism increasing the cambium surface and makes possible reconstruction of the cell arrangement $(\mathrm{H} \mathrm{e} \mathrm{j-}$ nowicz, 1967; Harris, 1973). It also play a decisive role in the process of cambium coalescence (Hejnow ic z 1963a, b). It occurs, finally during differentiation of the cells produced by the cambium. In storeyed cambium intrusive growth is not intensive, however, when it produces wood with interlocked grain intrusive growth is the mechanism leading to reconstruction of the cell arrangement ( $\mathrm{Hejnowicz,} \mathrm{Z} \mathrm{a-}$ gór s k a-M a r ek, 1974).

Intrusive growth may appear at any edge, but most frequently it is localized close to the corner. If it occurs beyond the cell ends it leads to forking of the latter. The occurrence of forked cells owing to intrusive. 

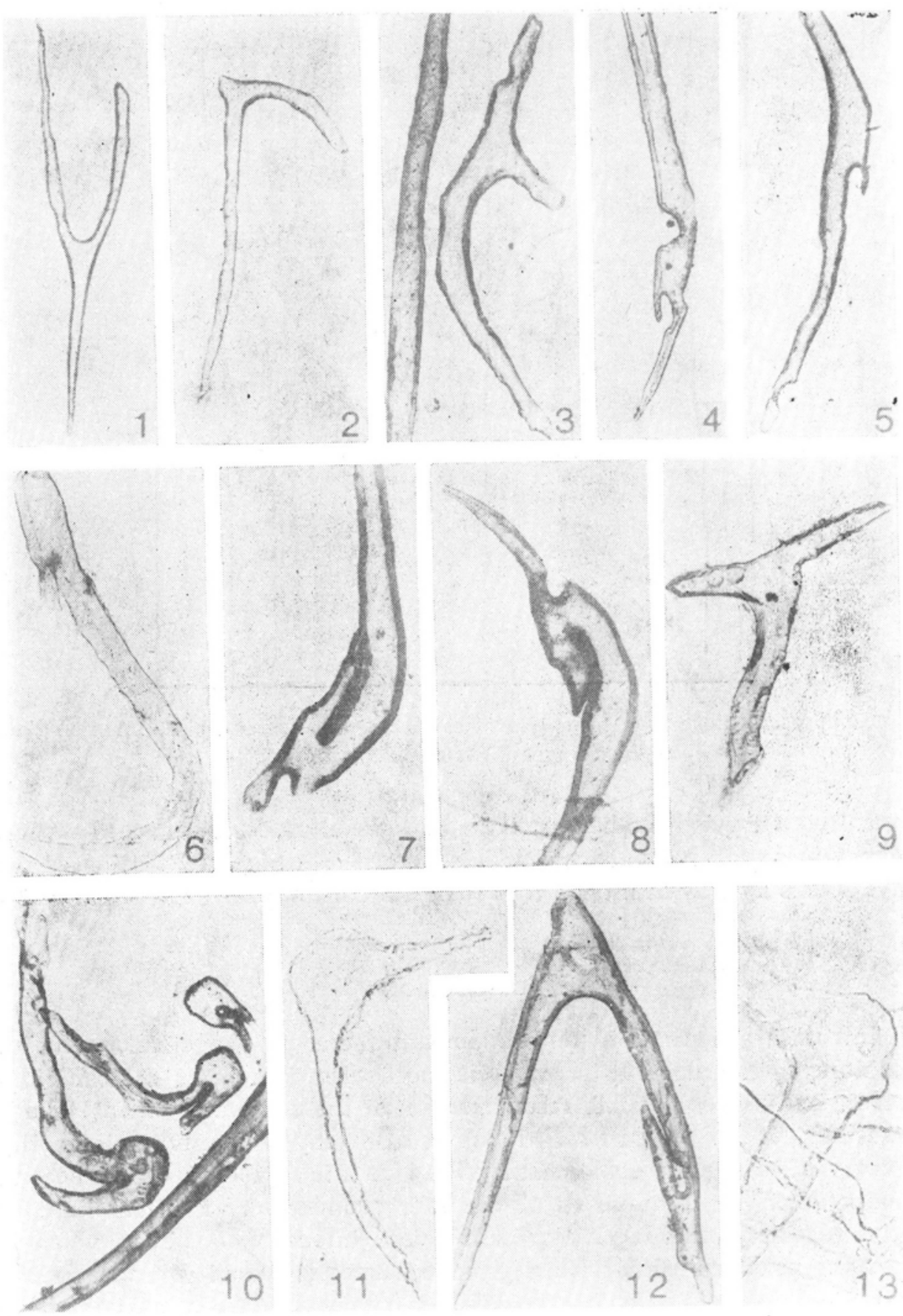

Fig. 10. Macerated tracheids with changed shape from whirled area:

1-9 branched tracheids; 12,13 - tracheids with cavity surrounded with wall; 10 - successive tracheids from one radial row; 11 - tracheid with distension 
growth has been described in wood formed on Abies alba and Picea excelsa stumps (N e eff, 1922), and also in fibres (S üs s, 1973) and sclereids. It would seem that the mechanism of choosing the direction of intrusive growth simply consists in choice of the edge for this growth, and this depends on the type of the domain ( $\mathrm{Hejnowicz}$, R o m b e r g e r, 1973). In view of the high dynamics of cell transformation in the whirled cambium it is difficult to establish the domain pattern. In the cambium fragments examined in the present study it was not possible to recognize this pattern. Normally intrusive growth in the cambium occurs between radial walls, it may, however, happen between tangential walls. A weak growth normally appears between the tangential walls at the site of elimination of the initial. A stronger growth between these walls disturbs the cell arrangement as has been here described.

It is interesting how strong intrusive growth occurs along the tangential walls. It results from the present investigations that conditions favourable to this are: running together of cells at a certain angle and accumulation of cell ends on a small area (Fig. 4C).

Cambium producing locally wavy wood differs from that forming normal wood by a higher intensity of the cellular events, and particularly by a higher rate of intrusive growth ( $\mathrm{Hejnowicz}$, 1971). The latter growth in a whirled arrangement is locally very intensive.

In the case of bent and forked cells the shapes are reproduced in the successive tangential layers only in the tangential plane. It results therefrom that periclinal divisions in the cambium occur in the tangential plane independently of the tridimensional shape of the cell (Fig. 11).

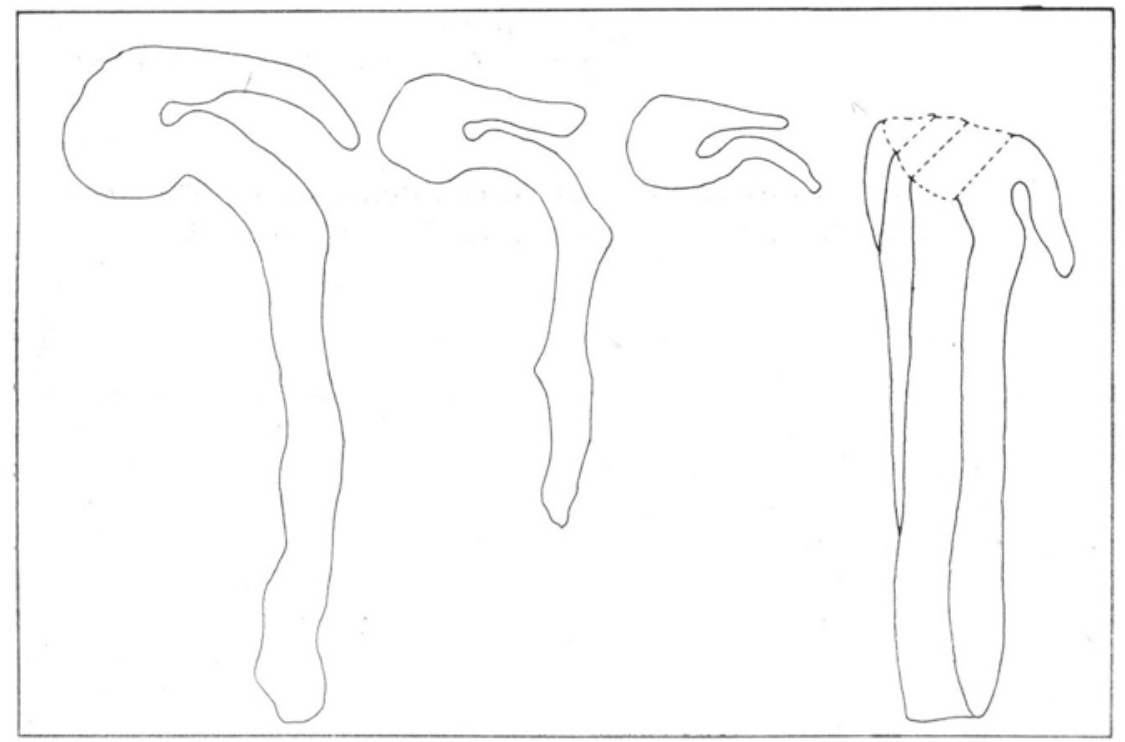

Fig. 11. Rapid elimination of bent cell. Three successive cells in eliminated row on right. Special diagram of this row - on left 
The author is deeply grateful to professor $\mathrm{Zygmunt} \mathrm{Hejnowicz}$ for his aid, precious advices and critical comments in the course of this work.

\section{REFERENCES}

H a r ris J. M., 1973, Spiral grain and xylem polarity in Radiata pine: microscopy of cambial reorientation, New Zealand Journal of Forestry Science 3 (3): $363-378$.

He jn owicz Z., 1963a, Wzrost intruzywny, podziały poprzeczne i skośne we wrzecionowatych komórkach inicjalnych zranionej miazgi modrzewia, Acta Soc. Bot. Pol. 32 (3): 493-503.

Hejnowicz Z., 1963b, Udział wzrostu intruzywnego w procesie zrastania się miazgi po poprzecznym nacięciu u modrzewia, Acta Soc. Bot. Pol. 32 (4): 625-630.

Hejnowicz Z., 1967, Interrelationships between cell length, rate of intrusive elongation, frequency of anticlinal divisions and survival of fusiform initials in cambium, Acta Soc. Bot. Pol. 36: 367-378.

Hejnowicz Z., 1971, Upward movement of the domain pattern in the cambium producing wavy grain in Picea excelsa, Acta Soc. Bot. Pol. 40 (3): 499-512.

H e jnowicz Z., R o m ber ger J. A., 1973, Migrating cambial domains and the origin of wavy grain in xylem of broadleaved trees, Amer. J. Bot. 60 (3): 209-222.

Hejnowicz Z., Z a górska-Marek B., 1974, Mechanism of changes in grain inclination in wood produced by storeyed cambium, Acta Soc. Bot. Pol. 43 (3): $381-398$.

N e eff F., 1922, Über polares Wachstum von Pflanzenzellen, Jahrb. f. wiss. Bot. 61: $205-283$.

S üss H., 1973, Zur Evolution des Holzstammes der Laubhölzer unter besonderer Berücksichtigung seiner Festigkeit, Feddes Repertorium 84 (7-8): 517-531.

Author's address:

Dr. Wiestaw Wtoch

Department Biophysics and Cell Biology,

Silesian University,

Jagiellońska Str. 28; 40-032 Katowice; Poland

\section{Zdarzenia komórkowe $w$ kambium zwiazane $z$ tworzeniem $i$ istnieniem zwichrowanego układu komórek}

\section{Streszczenie}

Badano drewno tumorowe $\mathrm{z}$ pnia drzewa Picea excelsa (Lam.) Lk. Na podstawie serii skrawków stycznych drewna prześledzono zdarzenia komórkowe, jakie zachodzą podczas tworzenia się i dalszego rozwoju zawichrowań komórek. Stwierdzono, że tworzą się one wtedy, gdy komórka inicjalna wzrasta intruzywnie między ściany sityczne komórek sąsiednich rzędów, poprzecznie do ich długiej osi. Zakłóca to gwałtownie wzrost intruzywny komórek w sąsiednich szeregach.

Wzrost intruzywny może wystąpić na dowolnej krawędzi komórki wrzecionowatej. Normalnie występuje na krawędziach promieniowych wierzchołkowych. Może jednak wystąpić na krawędziach promieniowych bocznych i bocznych podłużnych. Wzrost na krawędzi promieniowej bocznej doprowadza do rozgałęzienia się komórki.

Opisano komórki, których zagięty koniec rośnie po powierzchni ściany własnej komórki. Opisano również komórki z otworami otoczonymi ścianą. 